\title{
Study of a Stratigraphic Trap of Paleocene/Late Cretaceous Age with the Help of Seismic Data in Sulaiman Foredeep and Kirthar Foredeep Area (Central \& Southern Indus Basin, Pakistan)
}

\author{
Shazia Asim"1, Nasir Khan², Shahid Nadeem Qureshi ${ }^{3}$ Farrukh Hussain"1, \\ Saeed Ahmed Bablani ${ }^{4}$ \\ ${ }^{1}$ Department of Earth Sciences, Quaid-i-Azam University, Islamabad, Pakistan \\ ${ }^{2}$ Institute of Geophysics and Geomatics, China University of Geosciences (CUG), Wuhan, China \\ ${ }^{3}$ Department of Metrology, Comsats institute of Information Technology (CIIT), Islamabad, Pakistan \\ ${ }^{4}$ NREM, University of Kurdistan, Hewler, Iraq \\ Email: Shazia@qau.edu.pk, Shazia.asim1@gmail.com, s.bablani@ukh.ac
}

Received 11 July 2014; revised 6 August 2014; accepted 28 August 2014

Copyright (C) 2014 by authors and Scientific Research Publishing Inc.

This work is licensed under the Creative Commons Attribution International License (CC BY).

http://creativecommons.org/licenses/by/4.0/

\section{Abstract}

The Research work comprises area of Punjab Platform, Sulaiman Foredeep and Eastern Part of Sulaiman Fold Belt (from east to west), which is further extended to Zamzama and Dadu area of Lower Indus Basin. Seismic data interpretation suggests a presence of a stratigraphic trap of Paleocene/Late Cretaceous age. It can act as a stratigraphic trap of reservoir quality for hydrocarbons. This feature is marked and discussed on various seismic sections. Sometimes it is difficult to locate this feature due to effect of folding, resulting from later compressions associated with a collision of Indian Plate. This structure could be explored for a hydrocarbon prospect in future. Such stratigraphic traps were not explored in the past.

\section{Keywords}

Stratigraphic Trap, Shelf Margin, Seismic Interpretation, Central Indus Basin

\footnotetext{
${ }^{*}$ Corresponding author.
}

How to cite this paper: Asim, S., Khan, N., Qureshi, S.N., Hussain, F. and Bablani, S.A. (2014) Study of a Stratigraphic Trap of Paleocene/Late Cretaceous Age with the Help of Seismic Data in Sulaiman Foredeep and Kirthar Foredeep Area (Central \& Southern Indus Basin, Pakistan). International Journal of Geosciences, 5, 1049-1061. 


\section{Introduction}

Seismic lines are provided by DGPC and LMKR. The study of seismic profiles of length approximately 3500 $\mathrm{km}$ is done with the help of Well data, Formations’ tops, Synthetics and General stratigraphy of area. Structural and stratigraphical interpretation of seismic data is performed in detail. This is a first attempt in the research area which has ever been done before. This area is scarcely investigated in past. None of the previous work has mentioned this feature. This study is beneficial in various relevant fields such as Petroleum geology, Sedimentology, Seismic Stratigraphy, Structural geology, Tectonics, Geodynamics and Basin analysis for researchers and industries.

\section{Geology of Area}

Indus Basin is the largest basin oriented in NE-SW direction. Tectonically it is much stable area as compare to other tectonic zones of Pakistan. It comprises of buried ridges, platform slope, and zone of up warp and down warp [1]. The Indus basin is basically from the Khairabad-Panjal thrust to the Ornach-Nal \& Quetta fault system that runs along the western margin of the axial belt. The Kohat-Potwar, Sulaiman, Kirthar and the axial belt are different geological provinces of the Indus basin. The axial belt evolved on the NW margin of the Indian plate [2]. The area of the Middle and Lower Indus sub-basins is bounded by the Pizu-uplift to the north and the offshore Indus basin to the south and the Ornach-Chaman fault systems to the west [3].

\subsection{Divisions of Indus Basin}

a) Upper Indus Basin

b) Central Indus Basin

c) Southern Indus Basin

Central Indus may be divided into following broad tectonic divisions (from east to west) Punjab Platform, Sulaiman Depression \& Sulaiman Fold belt [4]. Punjab Platform marks a broad monoclinic structure dipping gently towards the Sulaiman depression. Sulaiman fold-and-thrust belt has been studied by [5] [6].

Research comprises of Sulaiman Foredeep and Kirthar Foredeep area (Figure 1). Sulaiman Foredeep is also called Sulaiman Depression. This depression is longitudinally oriented area of subsidence; it becomes arcuate and takes up a transverse orientation along its southern rim. Like many other features, this depression was also formed as a result of the collision between two plates [4]. The oblique collision between the Afghan block and the Indian subcontinent formed the Kirthar and Sulaiman Ranges. The Sulaiman Ranges are oriented in northsouth direction. The Southern \& Central Indus Basins are separated by Jacobabad \& Mari-Kandhkot highs together termed as the Sukkur Rift [7]. The southern Indus basin extends approximately between Latitude $24^{\circ} \mathrm{N}$ $28^{\circ} \mathrm{N}$ and from Longitude $66^{\circ} \mathrm{E}$ to eastern boundary of Pakistan (www.wikipedia.com).

It comprises of following five main units:

Thar Platform,

Karachi Trough,

Kirthar Foredeep,

Kirthar Fold Belt and

Indus offshore.

Kirthar Foredeep trends in North-South direction with a thickness of sediments over 1,5000 meters. It has a faulted Eastern Boundary with Thar platform. Paleocene is well developed in the depression and it is missing from Khairpur-Jacobabad High area. This depression is an area of great potential for the maturation of source rock [4].

\subsection{Stratigraphy of the Area}

The research area lies in Central Indus Basin of Pakistan (Figure 2). A complete stratigraphic correlation is made from the wells in east which are drilled in Paleozoic rocks (Darbula-01, Sarai Sidhu-01 and Bahawalpur East-01). The wells in western part of the area are drilled in Mesozoic rocks. They also indicate the presence of Late Oligocene-Early Miocene sediments. [8] describes the stratigraphy of Central Indus Basin as follows:

Precambrian Salt Range Formation with salt, marl, salt seams and dolomite forms the basement for the fossiliferous Cambrian sequence of the Salt Range. It represents an evaporate sequence similar to the Hormuz Salt 


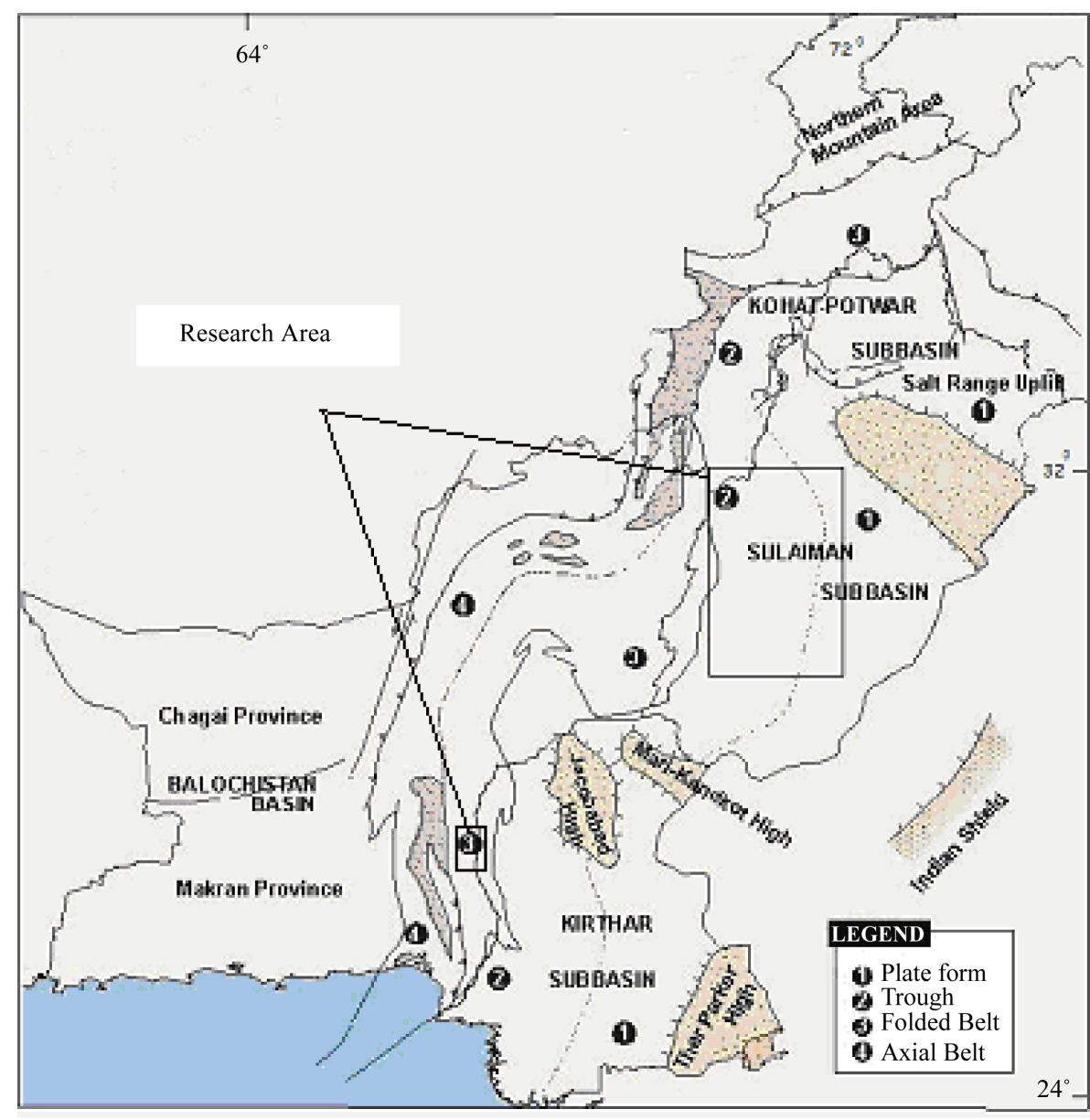

Figure 1. Geological map showing the location of research area (Courtesy of GSP).

Formation of Iran. Although its exposures are restricted to the Salt Range, deep drill holes have confirmed its presence to the north and south of the exposures. It has three members:

Sahwal, Marl Member

Bright, red marl beds with irregular gypsum, dolomite beds and Khewra Trap (3 - $100 \mathrm{~m}$ ). Also it has dull red marl beds with some salt seems and $10 \mathrm{~m}$ thick gypsum bed on top (more than $40 \mathrm{~m}$ ).

Bhandar Kas Gypsum Member

Massive gypsum with minor beds of dolomite and clay (more than $80 \mathrm{~m}$ ).

Billianwala Salt Member

Ferruginous red marl with thick seams of salt (more than $650 \mathrm{~m}$ ).

Its exposure is along the southern flank of the Salt Range, from Kussak in the east to Kalabagh in the west. In the subsurface, the rock unit is encountered as far south as Karampur in the Punjab Plains. Its contact with the overlying Khewra Sandstone is normal and conformable. Its age is assigned an Early Cambrian to Late Precambrian age.

\subsection{Paleozoic}

Rocks of Cambrian and Permian age are present in the Central Indus Basin. Cambrian rocks were essentially deposited in the shallow water except for the lower most and uppermost formation which represent transgressive and regressive facies respectively.

Cambrian: The Cambrian Formations are as follows:

Khewra Sandstone: The formation consists predominantly of purple to brown, yellowish brown, fine grained sandstone. The lower most part of the formation is red, flaggy shale. Sedimentary features like ripple marks and 
STRATIGRAPHY OF PAKISTAN

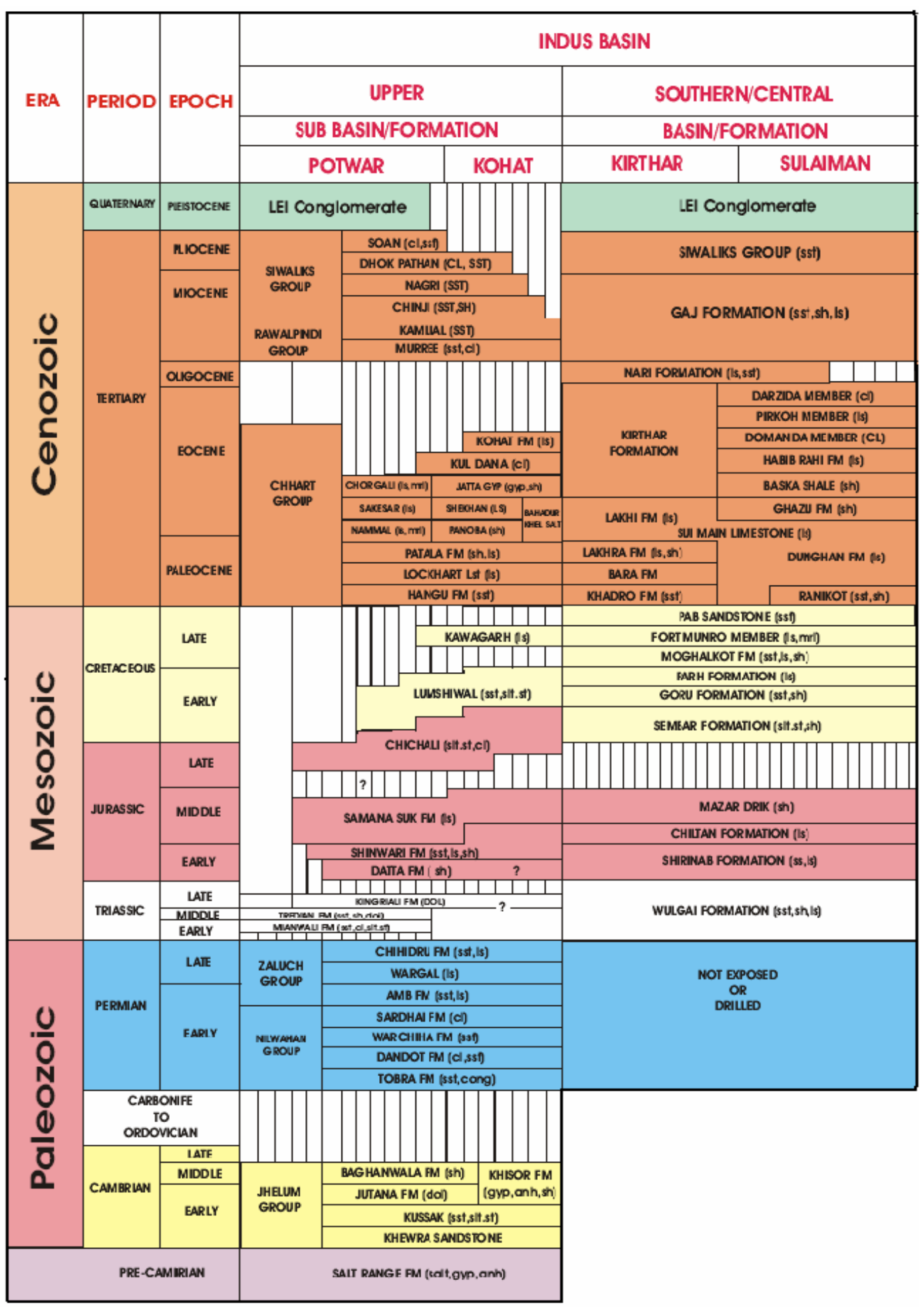

Figure 2. Stratigraphy of central indus basin (Kadri, 1995).

mud cracks are common in the formation. The age is Early Cambrian.

Kussak Formation: The formation is composed of greenish grey, glauconitic, micaceous sandstone, greenish grey siltstone, interbedded with light grey dolomite and some oolitic, arenaceous dolomite. Numerous layers of intraformational conglomerate are present. Pink gypsum lenses are present near the top. The age is Early Middle Cambrian. 
Jutana Formation

The formation consists of light green, hard, massive, partly sandy dolomite and the upper part is composed of light green to dirty white massive dolomite. Upper and lower contact with Baghanwala Formation and Kussak Formation respectively is conformable. The age is late Early Cambrian to early Middle Cambrian.

Baghanwala Formation

The formation is composed of red shale and clay, alternating with flaggy sandstone. Ripple marks and mud cracks are common in the formation. Numerous Pseudomorphic casts of salt crystals which are found along the bedding planes are diagnostic feature of this formation. They indicate the lagoonal environment and arid conditions for the deposition of the formation. The formation is encountered in the subsurface at Karampur. Its contact with the overlying Tobra Formation is unconformable. The age is early Middle Cambrian.

\subsection{Permian}

Permian rocks of the Axial Belt are exposed as isolated outcops in the core of anticlines. These exposures have been described from Wulgai, Ghazaband and Kalat areas of Baluchistan. Permian rocks are sedimentary with lithologies of shale, sandstone and limestone. These are divided into two groups:

Nilawahan Group: It consists of following formations:

Sardhai Formation

Warcha Formation

Dandot Formation

Tobra Formation

The Nilawahan Group represents a dominantly continental deposit consisting of arenaceous and argillaceous sediments with marine intertonging in the upper part which passes conformably into the overlying marine Zaluch Group. The lower most beds of the Permian rocks rests disconformably on Cambrian rocks while the upper part is separated from the Triassic rocks paraconformably.

Tobra Formation: This formation depicts a very mixed lithology in which the following three facies are recognized:

1. Tillitic facies exposed in the eastern Salt Range. This rock unit grades into marine sandstone containing Eurydesma and Conularia fauna.

2. Freshwater facies with few or no boulders. It is an alternating facies of siltstone and shale containing spore flora.

3. A complex facies of diamictite, sandstone and boulder bed.

Lower contact with the Cambrian rocks is disconformable. The age is Early Permian.

Dandot Formation: The lithology consists of light grey to olive green yellowish sandstone with the occasional thin pebbly beds and subordinate dark grey and greenish splintery shales. It has agradational contact with the underlying Tobra Formation and it is terminated in sharp but conformable contact with the overlying Warcha Sandstone. The age is Early Permian.

Warcha Sandstone: The formation consists of medium to coarse grained sandstone, conglomeratic in places and interbeds of shale. The sandstone is cross bedded and arkosic. The pebbles of the unit are mostly of granite of pink colour and of quartzite. It conformably overlies the Dandot Formation. It is overlain by the Sardhai Formation with the transitional contact. The age is Early Permian.

Zaluch Group: It consists of following formations:

Chhidru Formation

Wargal Formation

Amb Formation

Amb Formation: This formation consists of sandstone, limestone and shale. The sandstone beds occupy the lower part of formation. Upwards the sequence limestone with some shale appears. The upper contact with Wargal Limestone is conformable.

Wargal Formation: The lithology comprises dolomite of light to medium grey, brownish grey and olive grey colors. The upper contact with the Chhidru Formation is transitional. The age is Late Permian.

Chhidru Formation: The formation at the base has a shale unit. Overlying this unit are the beds of calcareous sandstone with few sandy limestone. The top most part of this formation is a white sandstone bed with oscillation ripple marks. The age is Late Permian. 


\subsection{Mesozoic}

Rocks of the Mesozoic Era are widely distributed in Pakistan. They depict a great variation in lithology and thickness in different parts of the country. Some important mineral deposits (barite, fireclay, low grade iron ores, phosphatic showings and others) and producing or potential oil and gas horizons are present within the rocks of Cretaceous and Jurassic Systems.

The Mesozoic rocks of the Lower Indus Basin are several thousand meters thick and are widely exposed in the Lower Indus Basin (Sulaiman-Kirthat province) and in the Axial Belt.

Triassic: Rocks of Triassic System are represented by Mianwali Formation, Tredian Formation, Chak Jabbi Limestone and Kingriali Formation in the Kohat Potwar Province and by the Wulgai formation in the Axial Belt. In the Axial Belt the Triassic System is represented by shale with subordinate limestone and sandstone of the Wulgai Formation. In the Upper Indus Basin the rocks of Triassic System mainly consist of limestone, dolomite, sandstone and shale and are divided into three formations

Permian-Triassic boundary: This boundary in Salt Range and Trans Indus ranges was placed at the top of the dolomite unit of the Kathwai Member of Mianwali Formation. Some placed the boundary in the middle of a white sandstone unit which is the highest bed of Chhidru Formation. This boundary where exposed is marked by a paraconformity.

Mianwali Formation: The age of the Mianwali Formation is Early Triassic.

It has following three members:

Narmia Member

Mittiwali Member

Kathwai Member

Kathwai Member: It consists of dolomite in the lower part and limestone in the upper part.

Mittiwali Member: It consists of grey, fine grained, non-glauconitic limestone with abundant ammonites. The rest of the unit consists of greyish shale, silty shale with some sandstone and limestone beds.

Narmia Member: The basal bed is of limestone. The rest of the unit consists of grey to black shale with interbeds of sandstone and lenticular limestone or dolomite. The top most bed is limestone.

Tredian Formation: This formation comprises of two members. The lower one is Landa Member which consists of sandstone and shale. The upper one is Khat Kiara Member is a massive, thick bedded, white sandstone that grades into the overlying Kingriali Formation. The age is of Middle Triassic.

Kingriali Formation: It consists of thin to thick bedded, massive, fine to coarse textured light grey brown dolomite and dolomitic limestone with interbeds of shale and marl in the upper part.

The lower contact with Tredian Formation is transitional which is marked by interbedding of sandstone and dolomite. The upper contact with the Datta Formation is disconformable. The age is Late Triassic.

\subsection{Jurassic}

The Jurassic System is represented by limestone, shale and sandstone with subordinate dolomitic and ferruginous beds. The lower part of the Lower Jurassic consists of arenaceous and argillaceous sediments of dominantly continental origin that grades up in the sequence into marine calcareous and argillaceous rocks. By Middle Jurassic, marine conditions were well established in most of the areas and mainly carbonate rocks were deposited. The close of the Middle Jurassic is marked by regressive facies. The Jurassic in the Axial Belt and Lower Indus Basin is represented by a great thickness (several thousand meters) of marine limestone and shale with subordinates in the lower part. Marine sedimentation continued during the Early Cretaceous and Jurassic-Cretaceous boundary is regarded as transitional.

Jurassic rocks are widely distributed in the Axial Belt and Sulaiman and Kirthar provinces of the Lower Indus Basin. Triassic rocks transitionally underlie Jurassic strata. The change in lithology is from a dominant shale of Triassic System to thin bedded limestone and intercalated shale of the early part of the Jurassic System. The Jurassic formations of the Lower Indus Basin comprises of:

Mazar Drik Formation

Chiltan Limestone

Shirinab Formation

Shirinab Formation: It consists of thin bedded limestone and shale, transitional to the underlying Triassic Wulgai Formation. The age is Early Jurassic. 
Chiltan Limestone: It consists of massive thick bedded limestone. Its upper contact with Mazar Drik Formation is transitional.

Mazar Drik Formation: It consists of thin bedded limestone and shale. Its upper contact with the Sember Formation is disconformable. It is not developed in the Sulaiman range.

The Jurassic System of the Upper Indus Basin is represented by Datta Formation (Early Jurassic), Shinwari Formation (Early to middle Jurassic) having three members Anjira Member, Loralai Limestone Menber and Spingwar Member, Samana Suk Formation (Middle Jurassic) and the lower part of the Chichali Formation.

\subsection{Cretaceous}

In the adjoining regions of Sulaiman and Kirthar provinces of the Lower Indus Basin the Cretaceous rocks are mostly of sedimentary origin and except for local disconformities constitute a continuous sequence from Early to Late Cretaceous. The overlying Tertiary sediments are transitional in parts of this area while local disconformities between the Cretaceous and Tertiary have been recognized.

The following formations have been recognized in the Sulaiman and Kirthar provinces:

Sember Formation

Goru Formation

Parh Limestone

Mughal Kot Limestone

Fort Munro Formation

Pab Sandstone

Moro Formation

In the Upper Indus Basin Kawagarh Formation, Lumshiwal Formation and Chichali Formation are recognized.

\subsection{Cenozoic}

The close of the Mesozoic Era is marked by the period of emergence in parts of Pakistan. There is an angular unconformity between Paleocene and the older units in parts of the Sulaiman province and Axial Belt. These rocks were deposited in a broad sea which gradually narrowed and retreated southward with the passage of time till it came to occupy its present position as Arabian Sea.

\subsection{Tertiary}

\section{Paleocene}

Limestone is the dominant lithology in most parts of the Lower Indus Basin, shale dominates in the Axial Belt and Eastern Sualiman Province.

Ranikot Group has Khadro Formation, Bara Formation (Lower Ranikot sandstone) and Lakhra Formation (Upper Ranikot limestone). It overlies Pab Sandstone unconformably. It is correlated with Dungan Formation.

\section{Eocene}

The shale and marl are the major lithology in the Early Eocene times in the Lower Indus Basin and adjoining areas of Axial Belt. Ghazij Formation, Laki Formation and Kirthar Formation are recognized in this area. Kirthar Formation is divisible into four members in parts of the eastern Sulaiman Province as Habib Rahi Limestone Member, Sirki Member, Pir koh Member and Drazinda Member.

Oligocene

Rocks of Oligocene age are developed in the Lower Indus Basin, Axial Belt and the Baluchistan Basin. Nari Formation of the Momani Group is recognized in the Kirthar Province, parts of Sulaiman Province and the Axial Belt. Nari Formation consists of sandstone, shale and subordinate limestone. It is conformably overlain by the Gaj Formation in the Sulaiman and Kirthar provinces. In the eastern part of Sulaiman range the contact is unconformable with Siwaliks as Gaj Formation is absent. Its age is Oligocene with some upper strata is of Early Miocene age (Shah, 1977). In the Sulaiman Range the Oligocene sequence which was previously referred to as Nari Formation has now been renamed as the Chitarwata Formation (Kazmi and Jan, 1997).

Miocene-Pliocene

The rock units recognized in the region of Indus Basin and Calcareous Zone of Axial Belt are as follows: 
Gaj Formation: It consists of shale with subordinate sandstone and limestone. Its lower contact with Nari Formatoin is transitional and conformable. The upper contact with Siwalik group is also transitional. The age is Early Miocene.

Rawalpindi Group: It consists of Murree Formation and Kamlial Formation.

Siwalik group

It consists of following formations:

Chinji Formation: It consists of red clay with subordinate ash grey or brownish grey sandstone. It is only confined to the southern half of the eastern Sulaiman Range and is not developed in the rest of the Lower Indus Basin. In the Sulaiman Range it disconformably overlies the Nari Formation. It is conformably overlain by Nagri Formation. The age is Late Miocene.

Nagri Formation: It consists of sandstone with subordinate clay and conglomerate. The upper contact with Dhok Pathan Formation is transitional. The age is Late Miocene.

Dhok Pathan Formation: It consists of cyclic alternations of sandstone and clay beds. Its upper contact with Soan Formation is gradational in the Lower Indus Basin. The age is Early to Middle Pliocene.

Soan Formation: It consists of compact, massive conglomerate with subordinate interbeds of varicoloured sandstone, siltstone and/or clay. The upper contact with the Lei Conglomerate is marked by an angular unconformity. However, in parts of the Lower Indus Basin and Quetta region, the contact has been transitional. The age is Late Pliocene to Early Pliestocene.

\subsection{Quaternary}

Lei Conglomerate is recognized in the Indus Basin and Quetta region of Axial Belt.

It is regarded as a valley fill, laid down as fluviatile, lacustrine and piedmont outwash deposits in the lower parts of the structural depressions. The formation is composed of coarser boulder and pebble conglomerates with minor coarse and cross bedded sandstone. The age is Early Pliestocene.

\section{Methodology}

Research is conducted in two parts. First the research is carried out in Leiah and Darya Khan of Dera Ismail Khan and also in Dera Ghazi Khan District of Central Indus Basin (Figure 1). Then research is extended to an area that lies between $26^{\circ} 00^{\prime} 00^{\prime \prime} \mathrm{N}-27^{\circ} 30^{\prime} 00^{\prime \prime} \mathrm{N}$ (latitude) and 67 $30^{\prime} 00^{\prime \prime} \mathrm{E}-68^{\circ} 30^{\prime} 00^{\prime \prime} \mathrm{E}$ (longitude), which lies near Dadu District (Lower Indus Basin), Sindh province. In Sulaiman Foredeep seismic line 845-LEA-114, 835-LEA-107 and C95/LMT-15 (Figure 3) has this feature. In Kirthar Foredeep seismic line HPK96-07 (Figure 4) which is a 60 fold seismic line oriented in East-West direction (19.8 km) shows same feature.

Stratigraphic correlation of seismic data of Sulaiman Foredeep is done with the help of following wells:

Kamiab-01, Saro-01, Budhuana-01, Drigri-01, Ramak-01, Domanda-01, Rhodho-01, Dhodak-01, Afiband-01, Zindapir-01, Gulan-01, Saviragha-01, Drigri-01, Kotrum-01, Sakhi Sarwar-01, Panjpir-01, Nandpur-01, Sarai Sidhu-01, Ahmedpur-01 and Behawalpur East-01.

Stratigraphic correlation of seismic data of Kirthar Foredeep is done with the help of following wells:

Zamzama-03,

Zamzama-North-01,

Zamzama-East-01 and

Phulji-01.

\section{Basemap}

Base map is showing locations and orientations of seismic lines (Figure 3, Figure 4).

\section{General Discussion}

Stratigraphical and Structural interpretation of seismic lines shows a very interesting feature in Paleocene/Late Cretaceous strata. It is a Stratigraphic Trap that due to collision, has been uplifted with rest of sediments in northern part of research area, making it difficult to identify. Figure 5 shows a seismic line located in the northern part of research area. The strata uplifted and there is an unconformity lying above this feature. It is difficult to identify on some of the seismic lines and sometimes it is confused with the other truncations and pinchout structures of area. It may be an ancient shelf margin feature. 


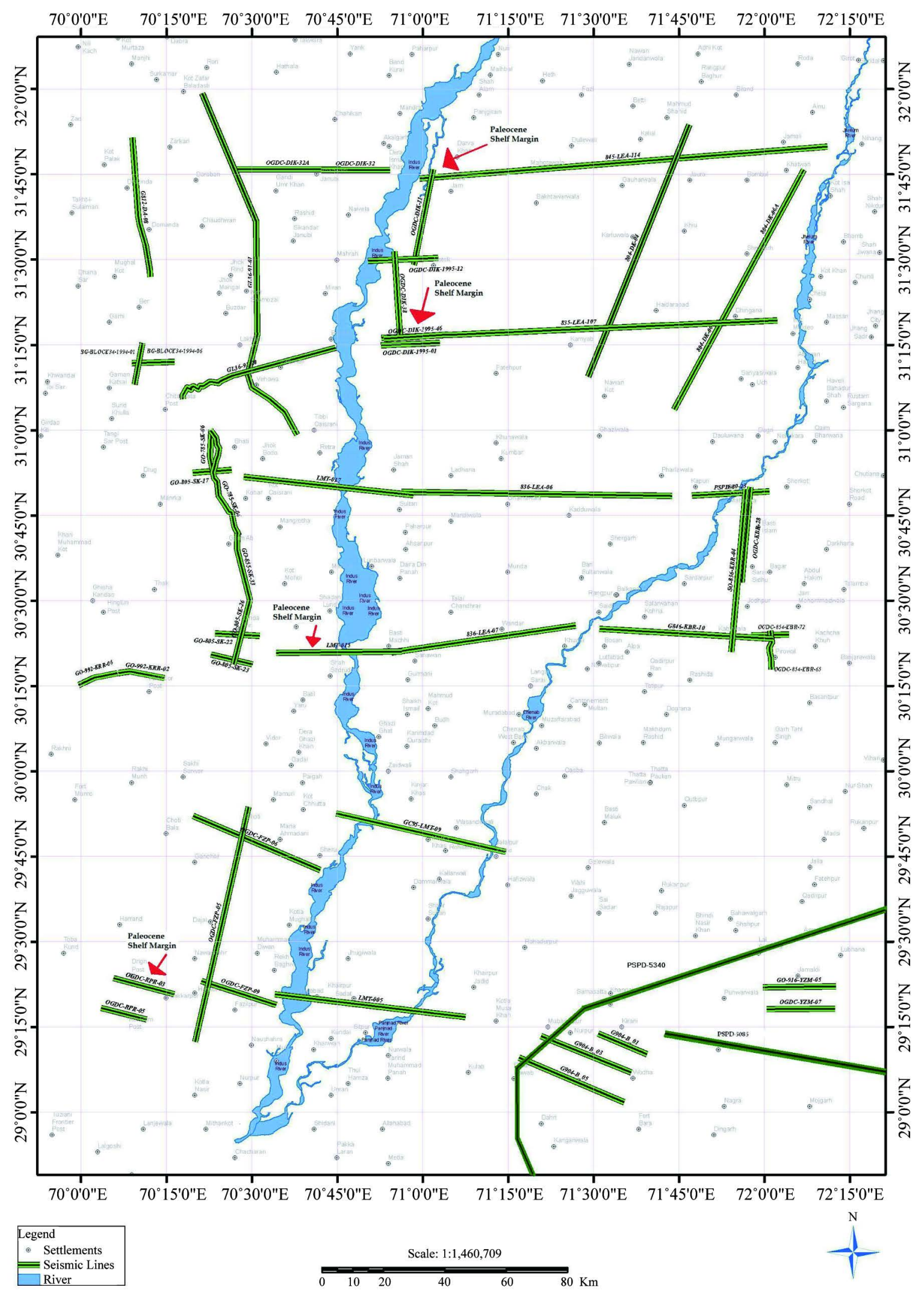

Figure 3. Basemap showing the location of seismic lines. Red arrow represents the feature. 


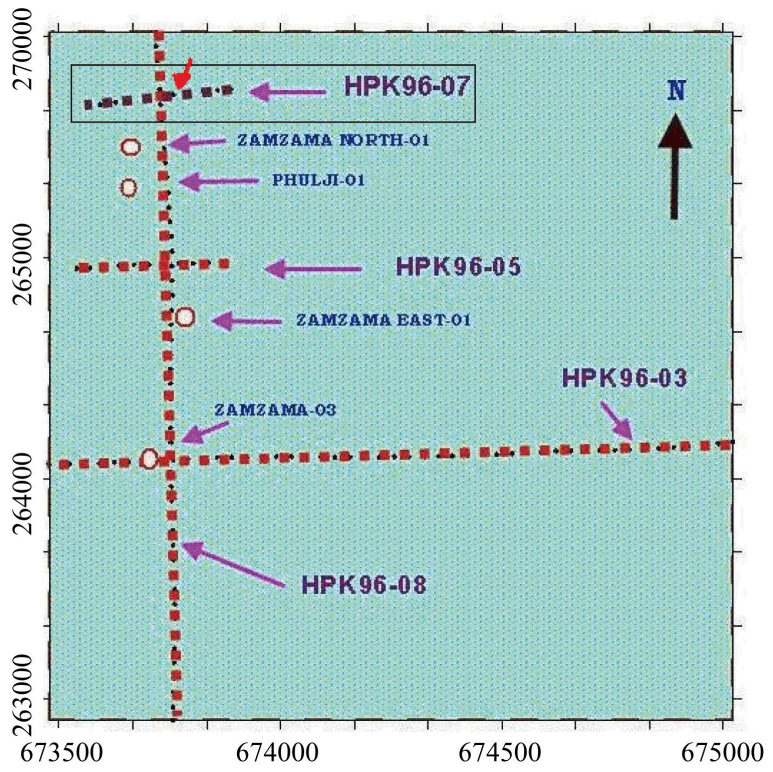

Figure 4. Basemap. Purple arrows are showing the location of seismic line HPK96-07 and wells Zamzama-03, Zamzama-North-01, Zamzama-East01 \& Phulji-01. Red arrow represents the feature.

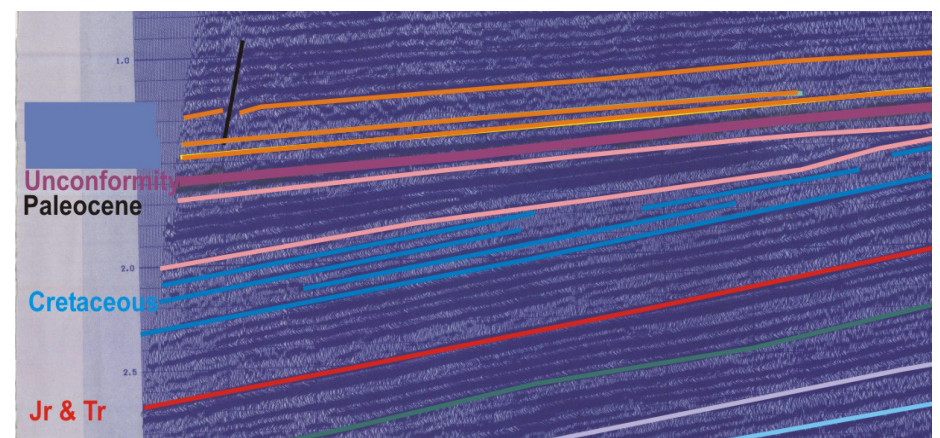

Figure 5. Feature is uplifted towards the Pezu Uplift in north (Seismic line 845-LEA-114).

In the south same feature is present in seismic line 835-LEA-107 under SP 280 and a very strong reflection is generated from here (Figure 6). Among other lines this is most prominent here.

This feature is also present in a seismic line C95/LMT-15 lying in the middle of research area (Figure 7). A Stratigraphic Trap of Paleocene age is faulted and folded due to later activity and represents a gentle synclinal structure.

Dunghan and Ranikot Formations of Paleocene act as a good reservoir rocks whereas the overlying shales of Eocene provide the good seals. The sources are buried deep with sufficient maturity levels. In the subsurface, Punjab Platform contains marine Paleozoic, Mesozoic and Neogene sediments. The zone is characterized by regional unconformities [7]. The same feature is studied in a Kirthar Foredeep area in Paleocene strata (Figure 8, Figure 9).

Due to folding it represents an anticlinal structure in the area. From S. P \# 1200 to S. P \# 1240, it is present in a core of anticline so it is less prominent and difficult to catch (Figure 9). There can be oil accumulation in this region in the hanging wall of a thrust sheet.

General subsurface trend of the Paleocene strata is given by a 3D depth model prepared in Figure 10. This model shows the uplift of the Paleocene strata towards Sargodha High and Pezu uplift in north and comparatively less uplift in Bahawalpur High area. The strata gets at deeper levels subsequently in west towards Sulaiman Foredeep and again uplifted in Safed Koh Trend and Sulaiman Fold Belt. 


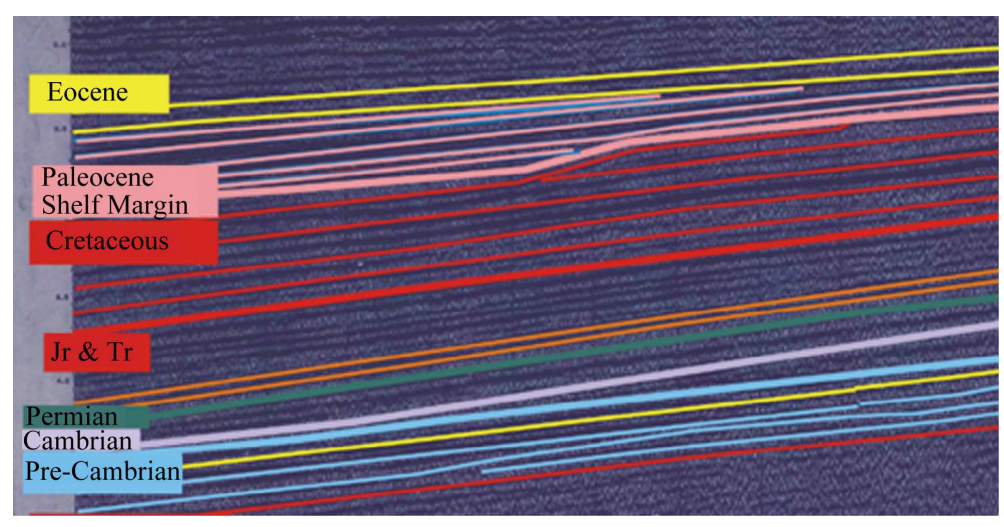

Figure 6. Shelf margin of paleocene age (Zoomed image of Seismic line 835LEA-107).

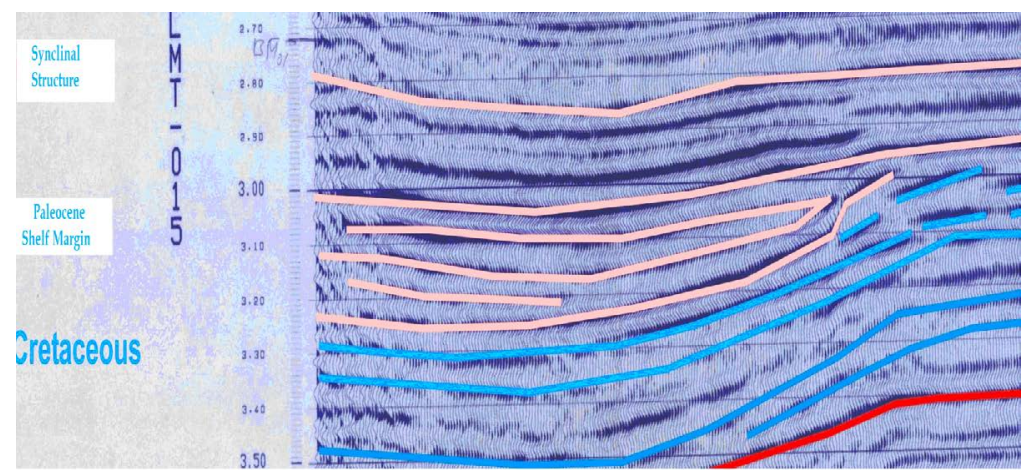

Figure 7. Stratigraphic trap of Paleocene age (Seismic line C95/LMT-15).

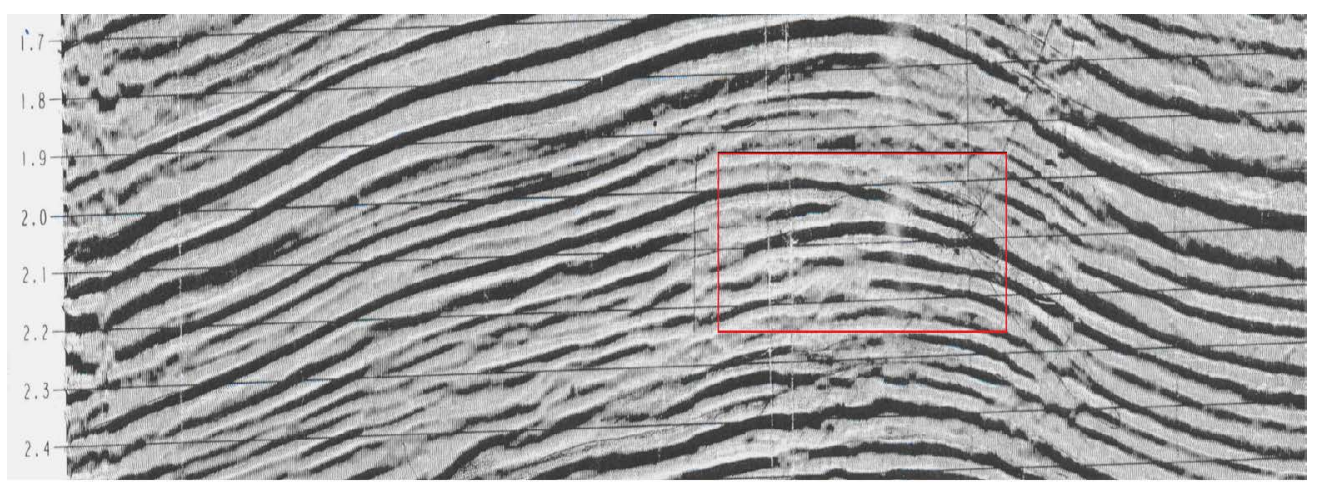

Figure 8. A stratigraphic trap which may be a shelf margin of Paleocene age on HPK96-07.

\section{Conclusions \& Recommendations}

There is a presence of Stratigraphic Trap of Paleocene age in the research area. This feature is marked on various seismic lines although it is difficult to catch it due to a tectonic activity which was carried out later on. In seismic line 845-LEA-114, near Pezu uplift in north it is uplifted due to collisional effect. In seismic line 835-LEA-107 it is most prominent. This is a stable area. In C95/LMT-15 it is folded into a syncline in Sulaiman Foredeep area and in HPK96-07 into an anticlinal structure in an area adjacent to Kirthar Fold Belt. Dunghan Formation could act as a Reservoir rock. Overlying Eocene shales (Ghazij Formation) could provide a perfect trap for hydrocarbons. The location of this feature is marked on the Basemap so a stratigraphic trap of the Paleocene age can be traced. This feature has never been studied earlier so it is highly recommended to explore it further and it should be treated as a prospect zone or zone of interest for hydrocarbons. 


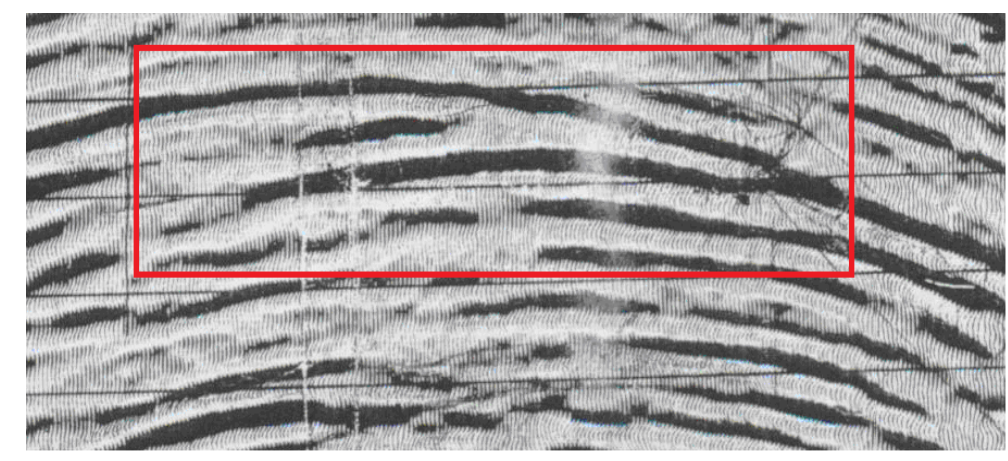

Figure 9. Shelf margin of Paleocene age on HPK96-07 which is folded due to a tectonic activity.

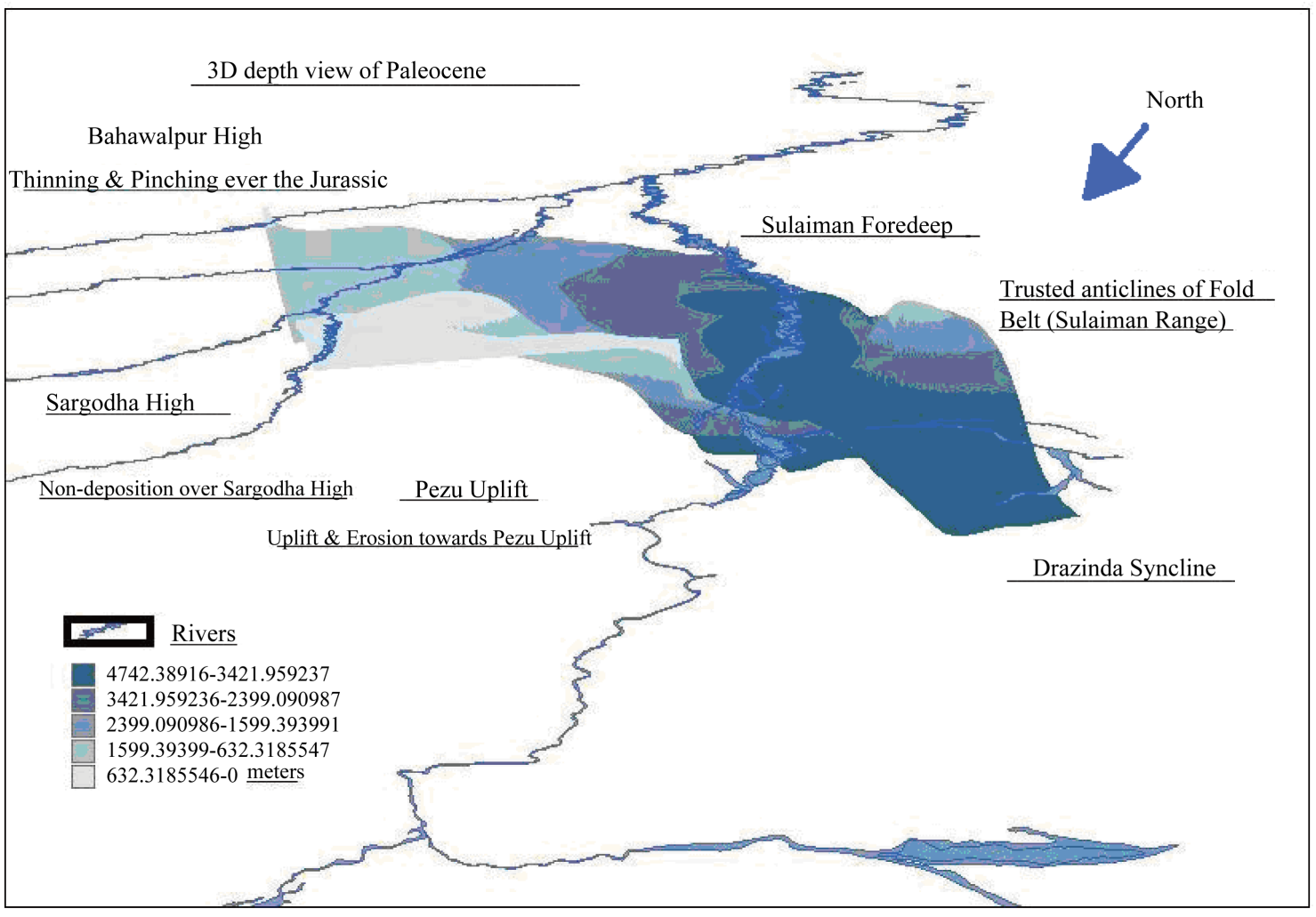

Figure 10. 3D sub-surface view of Paleocene sediments.

\section{Acknowledgements}

Landmark Resources (LMKR) and Directorate General of Petroleum Concessions (DGPC) are acknowledged for providing the data.

\section{References}

[1] Kazmi, A.H. and Jan, M.Q. (1997) Geology \& Tectonics of Pakistan. Graphic Publications, 650 p.

[2] Siddiqui, N.K. (2009) Sedimentary Basin Architecture of Pakistan and Summarized Stratigraphy of Pakistan in Proterozoic and Phanerozoic Integrated Stratigraphy (South-East Asia), India, Pakistan, Bangladesh, Myanmar and Sri Lanka. ONGC Bulletin, 44, 2.

[3] Khan, N., Zhu, P.M. and Konate, A.A. (2013) Petrophysical Parameters Estimation Using Geophysical Well Log Data of Indus Sub-Basin Area, Pakistan. Journal of Geography and Geology, 5, 71-82. 
http://dx.doi.org/10.5539/jgg.v5n4p71

[4] Kadri, I.B. (1995) Petroleum Geology of Pakistan. p. 34.

[5] Jadoon, I.A.K., Lawrence, R.D. and Lillie, R.J. (1992) Balanced and Retro Deformed Geological Cross-Section from the Frontal Sulaiman Lobe, Pakistan; Duplex Development in Thick Strata along the Western Margin of the Indian Plate. In: McClay, K., Ed., Thrust Tectonics, Chapman Hall, London, 343-356. http://dx.doi.org/10.1007/978-94-011-3066-0_31

[6] Jadoon, I.A.K., Lawrence, R.D. and Lillie, R.J. (1994) Seismic Data, Geometry, Evolution and Shortening in the Active Sulaiman Fold-and-Thrust Belt of Pakistan. Bulletin of the American Association of Petroleum Geologists, 78, 758-774.

[7] Raza, H.A., Ahmed, R., Ali, S.M. and Ahmad, J. (1989) Petroleum Prospects Sulaiman Sub Basin. Pakistan Journal of Hydrocarbon Research, 1, 21-56.

[8] Shah, S.M I. (1977) Stratigraphy of Pakistan: Geological Survey of Pakistan Memoir. Vol. 12, 138 p. 
Scientific Research Publishing (SCIRP) is one of the largest Open Access journal publishers. It is currently publishing more than 200 open access, online, peer-reviewed journals covering a wide range of academic disciplines. SCIRP serves the worldwide academic communities and contributes to the progress and application of science with its publication.

Other selected journals from SCIRP are listed as below. Submit your manuscript to us via either submit@scirp.org or Online Submission Portal.
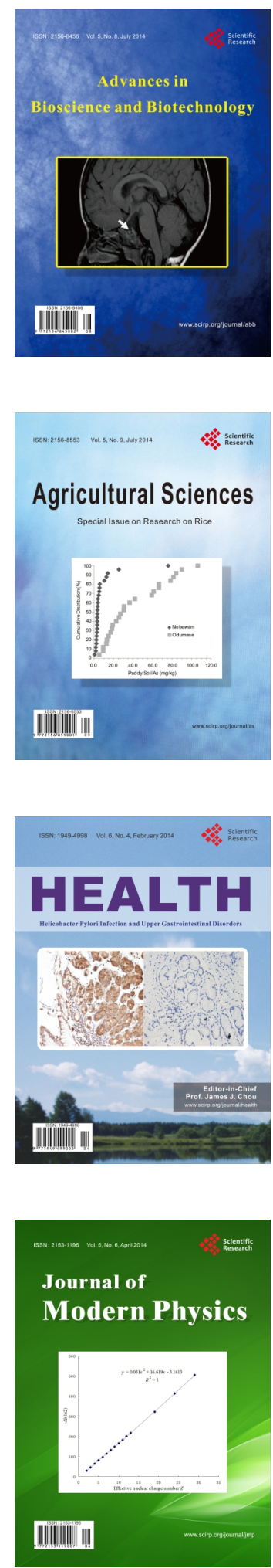
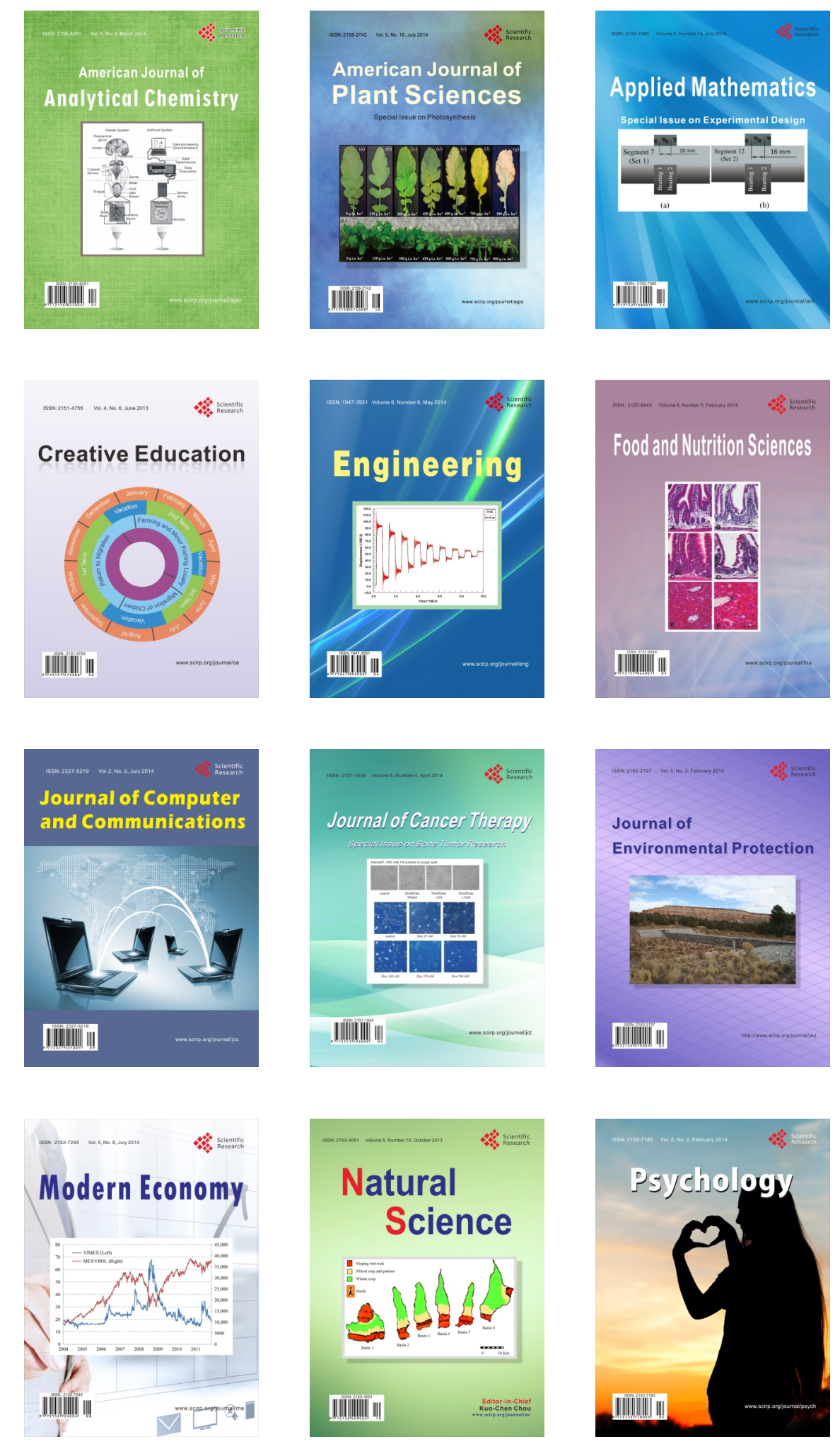